\title{
EFFECT OF FERTILIZATION AND BACKFILL AMENDMENTS ON SOIL CHARACTERISTICS, GROWTH, AND LEAF GAS EXCHANGE OF ENGLISH OAK (QUERCUS ROBUR L.)
}

\author{
By F. Ferrini' ${ }^{1}$, A. Giuntoli², F.P. Nicese ${ }^{3}$, S. Pellegrini ${ }^{4}$, and N. Vignozzi ${ }^{4}$
}

\begin{abstract}
The influence of fertilization and soil amendments on plant growth and leaf gas exchange was monitored on English oak trees (Quercus robur L.) over a 3-year period after planting. The results indicate that shoot growth, leaf area, chlorophyll content, and leaf gas exchange were higher in fertilized plants, especially during the second and third years after planting. However, compost and leonardite were rarely better than the control. Soil physical characteristics were positively influenced by soil amendments, which promoted a better structure and lowered penetration resistance compared to control and fertilization.

Key Words. Chlorophyll; compost; humate; photosynthesis; soil characteristics.
\end{abstract}

Various practices increase root growth by improving soil characteristics and are essential for a successful planting outcome in a stressful urban environment. The most common practices are incorporation of top soil, inorganic soil amendments, or organic soil amendments, such as composted materials. Positive effects from compost as a soil amendment at planting are often found in disturbed areas, where composted materials have demonstrated a certain efficacy, at least in the short term, in improving water retention capacity, organic matter content, soil density, and plant growth (Rakow 1992; Watson 1993; Day and Bassuk 1994; Smalley and Wood 1995; Kelting 1997; Watson and Himelick 1997).

Some attention has also been directed toward humic acids and their commercial forms, such as leonardite. The importance of humic substances lies in their ability to contribute to cation exchange capacity (Vetterlein and Hüttl 1999) and to establish nutrients regimes more similar to those of natural ecosystems in ways that cannot easily be mimicked by the use of mineral fertilizers (Greenly and Rakow 1995; Vetterlein and Hüttl 1999). Greater resistance to drought and winter injury has been documented, and accumulation of dry matter has also been attributed to humic acid application.

However, results obtained by the addition of humic substances and compost on soil physical properties are contradictory and don't always result in clearly positive results. While some authors found an increase in aggregate stability, a shift in pore distribution, or a decrease in bulk density, others found no changes in soil physical properties (Vetterlein and Hüttl 1999). The reason for this discrepancy might be the difference among soil types, and the results might also be affected by the type of organic matter applied. Research on the effects of these products is mostly reported for vegetable and fruit species (Obreza and Biggs 1989; Duval et al. 1998), and their efficacy on woody species in urban environments has not been determined.

As to fertilization, there is still a heated debate among arborists revolving around if, what, when, and how much fertilization is appropriate (Miller 1998, 2003; Marion 2003). At present, because of many contrasting results, there is no consensus on whether fertilizers should be applied to landscape trees (Marion 2003). The aim of the present study was, therefore, to evaluate the effects of backfill organic amendment and fertilization on posttransplant growth and physiological characteristics of Quercus robur L. trees and on soil physical characteristics in an urban park.

\section{MATERIALS AND METHODS Plant Material}

Before budbreak, 48 uniform, 5-year-old, 4 to $4.5 \mathrm{~m} \mathrm{(13} \mathrm{to}$ $15 \mathrm{ft}$ ) tall, 12 to $14 \mathrm{~cm}$ ( 5 to 6 in.) in circumference (measured at $1.3 \mathrm{~m}$ [4.3 ft] height), balled-and-burlapped (B\&B), grafted English oak (Quercus robur L.) trees were planted in a public park in Florence, Italy. All trees with identical size characteristics were obtained from the same nursery and planted at the same time.

Until the late 1970s, the park was used as a rubble dump to fill some drained ponds. The rubble was covered with a 80 to $100 \mathrm{~cm}$ (approximately $3 \mathrm{ft}$ ) layer of clayey soil. Planting holes were two times the width and one and a half times the depth of the root ball (size of the root ball was 40 to $45 \mathrm{~cm}$ [16 to $18 \mathrm{in}$.] in diameter). Trees were placed in the holes and backfilled with one of the following:

1. excavated soil with $50 \%$ composted yard waste obtained through aerobic biostabilization of selected organic residues; 
2. excavated soil plus leonardite, along with $2 \mathrm{~kg}$ [4.4 lb] of a commercial product known as Humisol ${ }^{\mathrm{TM}}$; or

3. excavated soil plus NPK (12-12-17) with magnesium (2), sulfur (5), and some microelements (boron [0.02] and zinc, [0.01]), along with $1 \mathrm{~kg}$ of commercial product known as Nitrophoska blu Spezial-BASF, with $5.5 \%$ nitric nitrogen and $6.5 \%$ ammoniacal nitrogen.

Holes backfilled with excavated soil were used as a control. The second and the third year after transplanting, all the treatments were repeated. The same amount of leonardite and fertilizer was applied immediately before budbreak, and $10 \mathrm{~kg}$ (22 lb) of compost was added around the planting hole by superficial hand-tilling $(<10 \mathrm{~cm}$ [4 in.], with no real damage to roots) with a hoe and mixing with the soil; all the other plants were hand-tilled at the same time. Trees were grown in a lawn situation with no removal of clippings, and the turf was not allowed to grow right up to the trunk.

Twelve single-plant replicates of four backfilling materials were planted in a completely randomized block design. Trees were watered, and some soil was added to compensate for settling. Trees in all treatments were irrigated once a week during spring and summer, with 40 to $50 \mathrm{~L}$ per plant (11 to 13 gal).

\section{Data Collection}

At the end of June, when no further shoot elongation was detected, shoot length was determined on 20 shoots per plant. Leaf area was calculated by measuring the area of 50 leaves per plant with a CID CI-203 leaf area meter (CID Inc., Vancouver, WA). Trunk diameter was measured at 30 and $120 \mathrm{~cm}$ (12 and $48 \mathrm{in}$.) above grade for 3 years on all plants just before budbreak.

Instantaneous net photosynthesis (Pn), transpiration rate (E), and water use efficiency (WUE, calculated by dividing Pn by E) were measured 75, 100, 123, and 150 days after budbreak (DABB) in the first year using the ADC-LCA-2 portable infrared gas analyzer; $75,100,130$, and $160 \mathrm{DABB}$ in the second year; and $60,75,90,120,135$, and 150 DABB in third year using the CIRAS-1 portable infrared gas analyzer (PP Systems, Hertfordshire, UK).

The readings were taken between 800 and 1800 hours on five fully expanded leaves per plant; the leaves were chosen from the outer part of the crown and at different heights, under conditions of natural light saturation (PAR > $1000 \mu \mathrm{mol} \mathrm{m}^{-2} \mathrm{~s}^{-1}$ ).

Chlorophyll content was determined in the second and third year after transplanting at 90 and 130 DABB on the same leaves with a portable chlorophyll meter (SPAD-502 Minolta Corp., Ramsey, NJ). Previous calibration curves were established by measuring absorbance at 664,647 , and $625 \mathrm{~nm}$ with an Hitachi U-2000 spectrophotometer, after extraction with dimethylformamide (DMF) (Moran 1982) $\left(R^{2}=93.3 \%\right.$, regr. eq. $\left.-9.84+0.713 x\right)$. Triplicate readings were taken around a midpoint near the midrib of each leaf sample and averaged.

At the end of the third year following transplanting, soil samples were taken to evaluate the influence of the various treatments on soil characteristics.

All the data regarding plants were analyzed using the one-way analysis of variance (ANOVA) using SPSS (Release 11.5 for Windows). Treatment means were separated by protected LSD, with $P \leq 0.05$ level of significance.

Soil physical characteristics were evaluated through bulk density, penetration (cone) resistance, and macroporosity measurements. Bulk density determination was performed using the core method (Blake and Hartge 1986) at 10 to 20 and 30 to $40 \mathrm{~cm}$ (4 to 8 and 12 to 16 in.) depths.

In-field penetration resistance was measured by a handheld electronic cone penetrometer (RIMIK model CP20), following ASAE standard procedures (1982). A 12 $\mathrm{mm}$ (0.5 in.) diameter cone with a 30-degree included angle and a $60 \mathrm{~cm}$ (24 in.) driving shaft was used, and data were recorded at $15 \mathrm{~mm}$ (0.6 in.) intervals. Nine replications (three measurements in three different locations) were carried out for each treatment; significance levels of the 0 to 15,15 to 30,30 to 45 , and 45 to $60 \mathrm{~cm}$ ( 0 to 6,6 to 12,12 to 18 , and 18 to 24 in.) depth cone resistance mean values were assessed by ANOVA (LSD test) at $P \leq 0.05$.

To evaluate the pore system of the soils, undisturbed soil samples from different depths (10 to 20 and 30 to $40 \mathrm{~cm} \mathrm{[4}$ to 8 and 12 to 16 in.]) were taken in triplicate. Samples were dried by acetone replacement (Miedema et al. 1974), impregnated with a polyester resin, and made into $6 \times 7 \mathrm{~cm}$ $(2.4 \times 2.8$ in.) vertically oriented thin sections (Murphy 1986). Images were captured with a video camera from each section. These images covered $4.5 \times 5.5 \mathrm{~cm}(1.8 \times 2.4 \mathrm{in}$. $)$ of the thin section, avoiding the edges where disruption could have occurred. The images were analyzed by image analysis techniques using Image-Pro Plus software produced by Media Cybernetics (Silver Spring, MD). The instrument was set up to measure pores larger than $50 \mu \mathrm{m}$. Pore shape factor was expressed as perimeter $2 /(4 \pi *$ area $)$. Using the shape factor, pores were divided into regular pores (shape factor 1-2), irregular pores (shape factor 2-5), and elongated pores (shape factor $>5$ ). Pores of each shape group were further subdivided into size classes according to either the equivalent pore diameter for regular and irregular pores, or to the width for elongated pores (Pagliai et al. 1984). Thin sections were also checked for microstructures using a Zeiss "R POL" microscope at $25 \times$ magnification. 


\section{RESULTS AND DISCUSSION}

Plant Growth and Leaf Gas Exchange, First Year

All plants had little growth when compared to the already minimal growth, which is typical the first year after planting, probably due to a period of drought and high temperatures that lasted the entire summer, but they all survived. This compares well with the average survival rate in Italy which is about $80 \%$ to $85 \%$. Leaf area was greater in the fertilized plants, while no effects were detected for the other parameters (Table 1). Photosynthesis and transpiration, as determined by leaf gas exchange data, were increased in the compost treatment, especially in the first part of the season (June and July and measurements; data not shown).

However, in assembling the four sampling dates, no significant data were found (Table 2).

Beginning in the middle of July, the plants showed symptoms of water stress, even with weekly irrigation. Numerous studies show that nitrogen applied later than about a month before budbreak seldom affects early season tree growth and may not be effective until the following season. Specific research on deciduous oaks (Quercus spp.) showed that leaf size and color were improved the next season, but little or no increase in shoot growth was evidenced until the following year (Harris et al. 2004).

\section{Plant Growth and Leaf Gas Exchange, Second Year}

During the second year, growth of the shoots was minimal. Compost and leonardite treatments registered significantly larger averages (Table 1). Leaf area and leaf dry weight were higher for fertilized trees. Fertilization increased photosynthesis and water use efficiency (Table 2). Contrary to the previous year's findings, addition of compost did not stimulate photosynthesis, probably because the greater amount of rainfall during the growing season masked any possible effect of the compost in terms of higher water retention ability. As for transpiration rate (E), it is difficult to identify a definite trend for the single treatments because the data were quite variable along the season. Considering the average data of four sampling dates, however, leaf evaporation rate was greater in the leonardite treatments.

WUE was lower later in the season, when transpiration values were similar to those in June and lower photosynthesis values were recorded (data not shown). This finding suggests the importance of ensuring an adequate supply of water for the trees, in the first part of the season when vegetative potential is very high and water use efficiency is clearly greater. In the second part of the season, lower photosynthetic potential of the plants (i.e., senescent leaves, shorter day length, and lower PAR values accompanied by greater probability of cloud cover) makes it less necessary to turn to external water sources, even if irrigation must be maintained in cases of drought and for species with a longer vegetative period.

More chlorophyll was present in the fertilizer treatment than any other treatment for both sampling dates (Table 3). Control plants had less total chlorophyll compared to the fertilizer and compost ones, while, when compared to the leonardite treatments, the differences were statistically significant only for the June measurement ( 90 days after budbreak, Table 3).

Table 1. Effect of backfill composition on shoot elongation (SE) $(\mathrm{cm})$, leaf area $(\mathrm{LA})\left(\mathrm{cm}^{2}\right)$, and leaf dry weight (DW) (g) of Quercus robur trees.

\begin{tabular}{|c|c|c|c|c|c|c|c|c|c|}
\hline \multirow[b]{2}{*}{ Treatment } & \multicolumn{3}{|c|}{ 1st year } & \multicolumn{3}{|c|}{ 2nd year } & \multicolumn{3}{|c|}{ 3rd year } \\
\hline & SE & LA & DW & $\overline{\mathrm{SE}}$ & LA & DW & SE & LA & DW \\
\hline Compost & $4.73 \mathrm{~ns}^{*}$ & $20.85 b$ & $0.14 \mathrm{~ns}$ & $4.84 \mathrm{a}$ & $20.91 \mathrm{~b}$ & $0.16 \mathrm{c}$ & $6.98 \mathrm{bc}$ & $30.88 \mathrm{~ns}$ & $0.22 \mathrm{~b}$ \\
\hline Fertilization & 4.40 & $25.74 \mathrm{a}$ & 0.18 & $4.19 \mathrm{~b}$ & $25.10 \mathrm{a}$ & $0.22 \mathrm{a}$ & $14.62 \mathrm{a}$ & 37.43 & $0.29 \mathrm{a}$ \\
\hline Leonardite & 4.02 & $22.2 \mathrm{~b}$ & 0.16 & $4.82 \mathrm{a}$ & $22.67 \mathrm{~b}$ & $0.18 \mathrm{~b}$ & $5.11 \mathrm{c}$ & 32.53 & $0.23 \mathrm{~b}$ \\
\hline Control & 3.89 & $20.63 \mathrm{~b}$ & 0.14 & $3.93 \mathrm{~b}$ & $22.18 \mathrm{~b}$ & $0.17 \mathrm{bc}$ & $8.37 \mathrm{~b}$ & 33.33 & $0.24 \mathrm{~b}$ \\
\hline
\end{tabular}

*Values differ significantly when followed by different letters at $P \leq 0.05$ (LSD test); ns = not significant.

Table 2. Effect of backfill composition on net photosynthesis (Pn), evaporation rate (E), and water use efficiency (WUE) of Quercus robur trees (Pn: $\mu \mathrm{mol} \mathrm{m}^{-2} \mathrm{~s}^{-1} \mathrm{CO}_{2}$; Evaporation rate: $\mu \mathrm{mol} \mathrm{m}^{-2} \mathrm{~s}^{-1} \mathrm{H}_{2} \mathrm{O}$; WUE: Pn/evaporation rate). Data are the average of four sampling dates in the first and second year and six sampling dates in the third year.

\begin{tabular}{|c|c|c|c|c|c|c|c|c|c|}
\hline \multirow[b]{2}{*}{ Treatment } & \multicolumn{3}{|c|}{ 1st year } & \multicolumn{3}{|c|}{ 2nd year } & \multicolumn{3}{|c|}{ 3rd year } \\
\hline & $\overline{\mathrm{Pn}}$ & $\mathrm{E}$ & WUE & $\overline{P n}$ & $\mathrm{E}$ & WUE & $\overline{\mathrm{Pn}}$ & $\mathrm{E}$ & WUE \\
\hline Compost & $8.15 \mathrm{~ns}^{*}$ & $1.50 \mathrm{~ns}$ & $5.43 \mathrm{~ns}$ & 9.92 c & $2.54 c$ & $3.90 \mathrm{~b}$ & $15.03 \mathrm{a}$ & $5.30 \mathrm{~ns}$ & $2.83 \mathrm{~ns}$ \\
\hline Fertilization & 7.69 & 1.00 & 7.69 & $12.24 \mathrm{a}$ & $2.64 c$ & $4.63 \mathrm{a}$ & $16.05 \mathrm{a}$ & 5.40 & 2.97 \\
\hline Control & 7.52 & 1.05 & 7.16 & $11.02 \mathrm{~b}$ & $2.85 \mathrm{~b}$ & $3.86 \mathrm{~b}$ & $13.18 \mathrm{~b}$ & 5.04 & 2.62 \\
\hline
\end{tabular}

*Values differ significantly when followed by different letters at $P \leq 0.05$ (LSD test); ns = not significant. 
Table 3. Total chlorophyll content $\left(\mu \mathrm{cm}^{-2}\right) 90$ and 130 days after budbreak (DABB) as affected by different planting hole backfill soils in the second year and third year of research on Quercus robur trees.

\begin{tabular}{llllll}
\hline & \multicolumn{3}{c}{ 2nd Year } & & \multicolumn{2}{c}{ 3rd year } \\
\cline { 2 - 3 } \cline { 5 - 6 } Treatment & Chlorophyll & Chlorophyll & & Chlorophyll & Chlorophyll \\
90 DABB & 130 DABB & & 90 DABB & 130 DABB \\
\hline Compost & $14.90 \mathrm{~b}^{*}$ & $13.08 \mathrm{~b}$ & & $15.26 \mathrm{~b}$ & $13.79 \mathrm{bc}$ \\
Fertilization & $17.13 \mathrm{a}$ & $16.92 \mathrm{a}$ & & $18.09 \mathrm{a}$ & $17.21 \mathrm{a}$ \\
Leonardite & $14.92 \mathrm{~b}$ & $12.61 \mathrm{c}$ & & $14.54 \mathrm{~b}$ & $14.16 \mathrm{~b}$ \\
Control & $12.93 \mathrm{c}$ & $12.27 \mathrm{c}$ & & $14.89 \mathrm{~b}$ & $12.81 \mathrm{c}$ \\
\hline
\end{tabular}

*Values differ significantly when followed by different letters at $P \leq 0.05$ (LSD test); ns = not significant.

\section{Plant Growth and Leaf Gas Exchange, Third Year}

Shoot extension was much greater in the fertilized trees (Table 1). This finding is different from other studies that indicate that if there is a benefit from fertilization after planting, it is not very relevant (Struve 2002). Other investigations suggest that it is of secondary importance after irrigation (Herms 1998). However, some evidence exists demonstrating how the response to fertilizers is variable depending on species, tree size, type of planting material (container or B\&B, plant size, etc.), and soil quality (Funk 2003). The few studies carried out in this field have, in fact, shown that whenever trees are regularly watered, they benefit notably from a balanced supply of nutrients (Gilman 1994). It is, therefore, probable that in the first season following planting, an absence of rainfall accompanied by high temperatures and the stress quite common after transplanting may have a limiting effect on the mineral elements added to the planting hole. This hypothesis is consistent with findings that showed that though there was no response to fertilization in the first year after transplanting, fertilized trees grew more in the second, third, and fourth years after transplanting (Wyman 1936; Gilman and Yeager 2003).

Considering the data collected during the entire season, photosynthesis was greater in fertilized plants, while no significant effect was produced with regard to transpiration and water use efficiency (Table 2). Fertilized trees showed significantly higher values of chlorophyll at both sampling dates, while the control plants had clearly lower values (Table 3).

\section{Soil Physical Characteristics}

Measured bulk density values are given in Table 4. Statistical analysis did not show significant differences for treatments and sampling depth, even though slightly lower bulk density values were observed in the soil amended with leonardite. However, bulk densities able to restrict root growth $\left(r_{b}>1.47\right.$ for soil with more than $45 \%$ clay) (NRCS Soil Quality Institute 1999) were never observed in the soil surrounding the planting hole.
Cone resistance decreased in soil amended with compost and leonardite with respect to control and fertilization treatments (Figure 1). This finding indicate a noteworthy improvement in soil physical conditions, considering that penetrometer resistance has been found to correlate with some quantitative and qualitative parameters, such as crustability, compressibility, workability, erodibility, bulk density, root growth, seedling emergence, and plant yield (Bradford 1986; Dexter 1987). Compost addition exhibited significantly lower penetrometric resistance respect to control and fertilization treatments along the whole soil profile ( 0 to $60 \mathrm{~cm}$ [0 to 24 in.]). Moreover, backfill soil added with compost and leonardite never showed cone resistance values $(>2000 \mathrm{kPa})$ (Schafer et al. 1992) that may seriously restrict root elongation.

Total macroporosity and porosity values regarding different pores type at two sampling depth are reported in Table 5. Both treatments failed to show differences in total porosity at 10 to 20 and 30 to $40 \mathrm{~cm}$ ( 4 to 8 and 12 to 16 in.) depths, indicating a rather homogeneous distribution throughout the soil profile.

Regular and irregular pores were not affected by various treatments. The elongated pores significantly increased in the leonardite- and compost-amended soil compared to control and fertilization treatments. Because it has been widely demonstrated that the increase of elongated pores improves the soil structure quality (Pellegrini et al. 2000; Pagliai and Vignozzi 2002), these results indicate the presence of a better soil structure after the addition of leonardite and compost.

For a thorough characterization of soil macropores, the main aspects to be considered are not only pore shape but also pore size distribution, especially of elongated continuous pores, because many of these pores directly affect plant growth by easing root penetration and storage and transmission of water and gases. For example, pores of equivalent pore diameter ranging from 0.5 to $50 \mathrm{~mm}$ are the storage pores, which function as a water reservoir for plants and

Table 4. Effect of treatments on soil bulk density $\left(\mathrm{g} \mathrm{cm}^{-3}\right)$ at 10 to 20 and 30 to $40 \mathrm{~cm}$ (4 to 8 and 12 to $16 \mathrm{in}$.) depths.

\begin{tabular}{lll}
\hline & \multicolumn{2}{c}{ Sampling depth } \\
\cline { 2 - 3 } Treatment & $10-20 \mathrm{~cm}$ & $30-40 \mathrm{~cm}$ \\
\hline Compost & $1.30 \mathrm{~ns}^{*}$ & $1.30 \mathrm{~ns}$ \\
Leonardite & 1.17 & 1.16 \\
Fertilization & 1.29 & 1.29 \\
Control & 1.25 & 1.33 \\
\hline
\end{tabular}

*Values differ significantly when followed by different letters at $P \leq 0.05$ (LSD test); ns = not significant. 


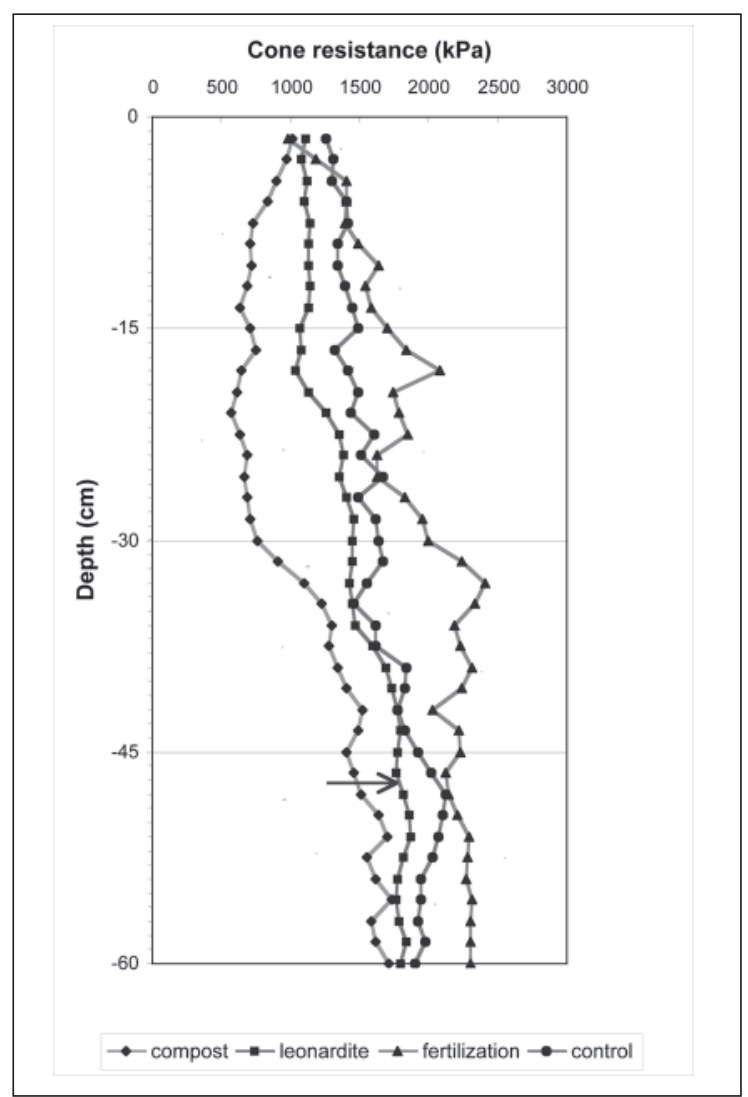

Figure 1. Effect of treatments on cone resistance. In each soil layer ( 0 to 15,15 to 30,30 to 45 , and 45 to $60 \mathrm{~cm}$ [0 to 6,6 to 12,12 to 18 , and 18 to 24 in.]), mean values differ significantly when followed by different letters at $\boldsymbol{P} \leq$ 0.05 (LSD test).

microorganisms; the transmission pores (elongated and continuous pores), ranging from 50 to $500 \mathrm{~mm}$, are particularly important in soil-water-plant relationships. Damage to soil structure can be recognized by a decrease in the proportion of transmission pores (Pellegrini et al. 2000).

Figure 2 shows pore shape and size distribution for different treatments at 10 to $20 \mathrm{~cm}$ (4 to 8 in.) depth. The soil treated with compost and leonardite showed a very high proportion of elongated transmission pores, especially those larger than $500 \mathrm{~mm}$. Pores larger than $500 \mathrm{~mm}$ are important for soil aeration and drainage (especially in heavy textured soils) and for root penetration. The same behavior was observed at 30 to $40 \mathrm{~cm}$ (12 to 16 in.) depth (data not shown).

Macroporosity measurements of the control soil showed the presence of low porosity values for all pores type and size classes both at 10 to 20 and 30 to $40 \mathrm{~cm}$ ( 4 to 8 and 12 to 16 in.) depths. Fertilized soil exhibited a pore size distribution similar to the control, except for an higher quantity of wide (>1000 mm), irregular pores at 10 to 20 cm (4 to 8 in.) depth (Figure 2). However, microscopic observation of soil thin sections (Figure $3 \mathrm{c}$ ) revealed a poor continuity of these type of pores. The thin sections of the control (Figure 3d) confirmed the presence of a rather massive soil structure, while micromorphological examination of thin sections of soil amended with compost (Figure 3a) showed a well-defined subangular blocky structure and the presence of vertically oriented elongated pores. Soil amended with leonardite evidenced very large elongated pores (fissures), positively affecting downward water movement. An overall insight of the soil pore system show a rather low intra-aggregate porosity (Figure 3b), indicating that this type of amendment is less effective than compost in terms of structuring capability.

\section{CONCLUSIONS}

The initial period after planting is the most critical for success and is decisive for the tree's survival. However, it is widely believed that trees, after the initial shock, recover in the following years, once root system functions have been restored. This may happen, but frequently the opposite occurs: trunk and root growth remain closely correlated to that of the previous year. Some trees die after 4 to 5 years of stunted growth; others, after the same period of time, are able to recover, but in the meantime their aesthetic value is reduced and they end up being smaller than their predicted size.

The results of the present study point out that, whenever adequate water is ensured, the most important factor for trees is fertilization. Above all, in the second and third years, tree fertilization was a determinant for greater photosynthesis, total chlorophyll, and leaf area values when compared with the

Table 5. Effect of treatments on different pore types and total macroporosity of the 10 to 20 and 30 to $40 \mathrm{~cm}(4 \mathrm{to} 8$ and 12 to 16 in.) layers, expressed as a percentage of area occupied by pores larger than $50 \mathrm{~mm}$ per thin section. Porosity values differ significantly when followed by different letters at $P \leq 0.05$ (LSD test).

\begin{tabular}{|c|c|c|c|c|c|c|c|c|}
\hline \multirow[b]{2}{*}{ Treatment } & \multicolumn{2}{|c|}{ Regular pores } & \multicolumn{2}{|c|}{ Irregular pores } & \multicolumn{2}{|c|}{ Elongated pores } & \multicolumn{2}{|c|}{ Total porosity } \\
\hline & $10-20 \mathrm{~cm}$ & $30-40 \mathrm{~cm}$ & $10-20 \mathrm{~cm}$ & $30-40 \mathrm{~cm}$ & $10-20 \mathrm{~cm}$ & $30-40 \mathrm{~cm}$ & $10-20 \mathrm{~cm}$ & $30-40 \mathrm{~cm}$ \\
\hline Compost & $1.94 \mathrm{~ns}^{*}$ & $2.60 \mathrm{~ns}$ & $3.56 \mathrm{~ns}$ & $3.80 \mathrm{~ns}$ & $5.76 \mathrm{ab}$ & $5.41 \mathrm{ab}$ & $11.27 \mathrm{a}$ & $11.82 \mathrm{a}$ \\
\hline Leonardite & 2.01 & 1.88 & 4.76 & 3.42 & $7.62 \mathrm{a}$ & $10.14 \mathrm{a}$ & $14.39 \mathrm{a}$ & $15.44 \mathrm{a}$ \\
\hline Fertilization & 1.35 & 1.49 & 3.06 & 2.17 & $1.50 \mathrm{~b}$ & $1.98 \mathrm{~b}$ & $5.92 \mathrm{~b}$ & $5.64 \mathrm{~b}$ \\
\hline Control & 1.54 & 2.06 & 2.22 & 2.82 & $0.73 \mathrm{~b}$ & $1.44 \mathrm{~b}$ & $4.50 \mathrm{~b}$ & $6.32 \mathrm{~b}$ \\
\hline
\end{tabular}

*Values differ significantly when followed by different letters at $P \leq 0.05$ (LSD test); ns = not significant. 


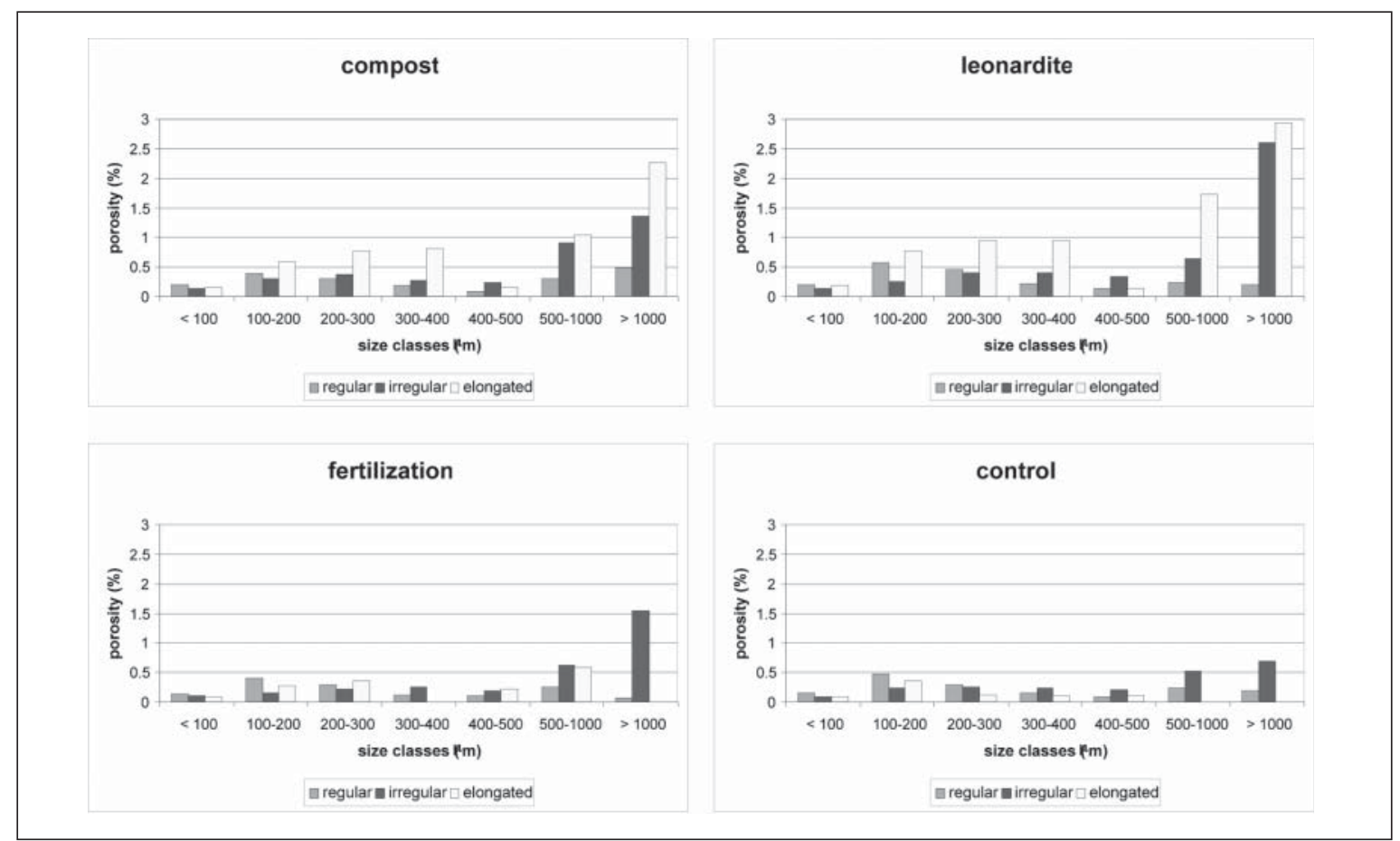

Figure 2. Pore size distribution, expressed as equivalent pore diameter, for regular and irregular pores and width for elongated pores, in the 10 to $20 \mathrm{~cm}$ (4 to 8 in.) layer.

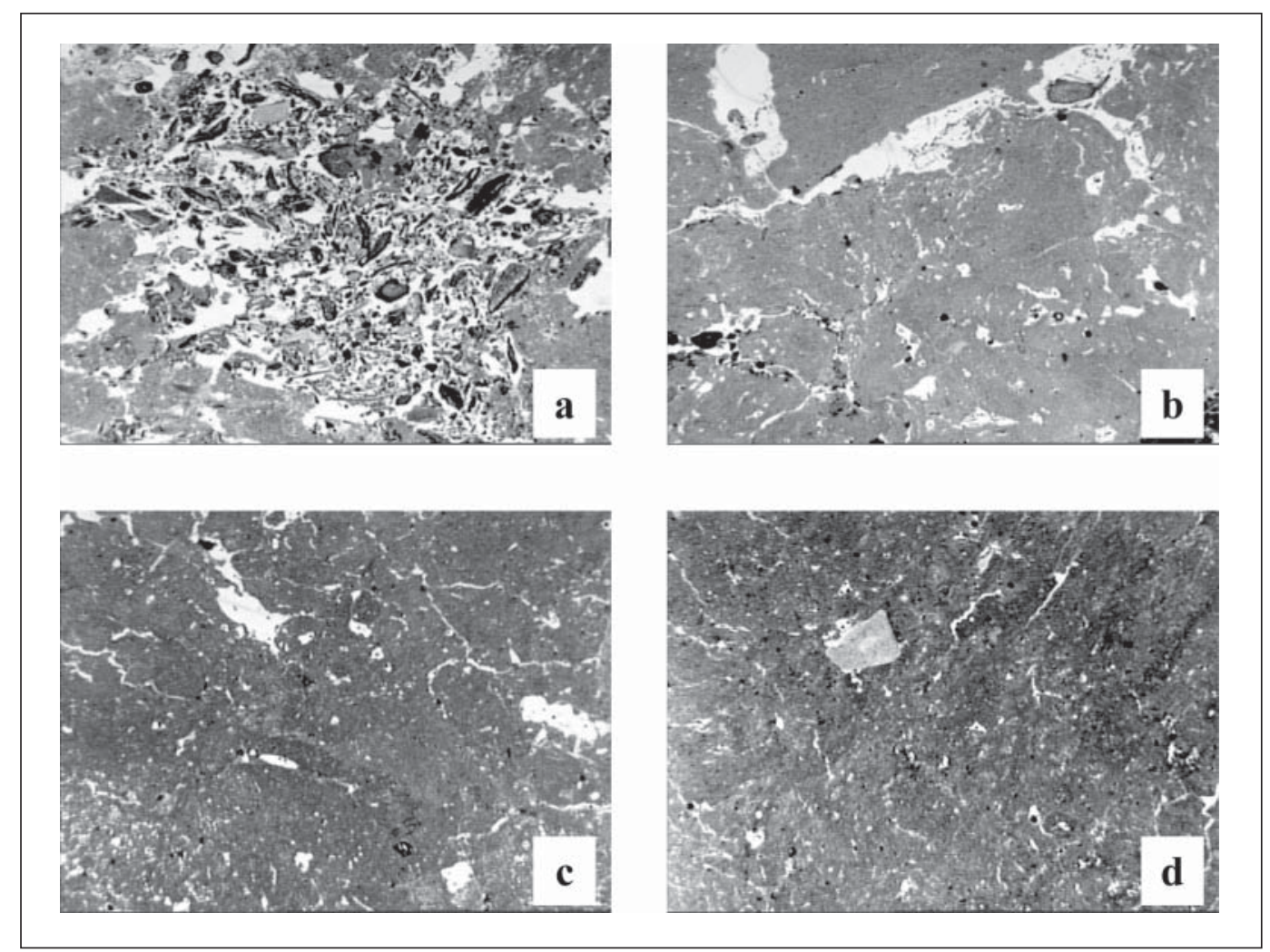

Figure 3. Macrophotographs of vertically oriented thin sections prepared from undisturbed samples from the 10 to $20 \mathrm{~cm}$ ( 4 to $8 \mathrm{in}$.) layer of soil under different treatments (a: compost; b: leonardite; c: fertilization; d: control). Frame length $3.5 \times 2.8 \mathrm{~cm}(1.4 \times 1.1 \mathrm{in}$.). 
other treatments. Shoot length in this study, however, was less influenced by fertilization (particularly in the first and second year), leading to the hypothesis of a probable predetermination of this parameter in the shoot primordia present on the trees and formed during the previous year; therefore fertilization applied right before planting seldom affects season growth and may not be effective until the following year (Gilman and Yeager 2003; Harris et al. 2004). In the third year, once the post-transplant crisis was overcome and trees were established, the trees responded to fertilization in an extremely positive way, exhibiting increases in growth that were nearly double those of the other treatments.

As to soil characteristics, the addition of compost and leonardite to the backfill soil positively affected soil physical properties compared to fertilization and control treatments. In particular, cone resistance significantly decreased in the soil amended with compost up to $60 \mathrm{~cm}$ (24 in.) depth. Amended soil showed higher total macroporosity values both at 10 to 20 and 30 to $40 \mathrm{~cm}$ (4 to 8 and 12 to 16 in.) depths. Moreover quantity and size distribution of elongated transmission pores indicated a better quality of the pore system. On the contrary, micromorphological examination of soil thin sections showed a poor spatial arrangement of this type of pore in the fertilized soil, along with the presence of a massive structure in the control treatment.

While the data obtained are limited to only one species and one environment, they provide a solid base for continuing studies. Future investigations should lead to a better definition of the techniques related to backfilling, on both the plants and the physical-chemical characteristics of the soil, which, in the long-term, may be positively modified to produce differences in plant growth and physiology that have not emerged during the first 3 years following transplant.

\section{LITERATURE CITED}

American Society of Agricultural Engineers (ASAE). 1982. Soil penetrometer, Agricultural Engineering Yearbook, ASAE Standard, ASAE S313.1, American Society of Agricultural Engineers, St. Joseph, MI.

Blake, G.R., and K.H. Hartge. 1986. Bulk density, pp. 363382. In Klute, A. (Ed.). Methods of Soil Analysis, Part 1 (2nd ed.). American Society of Agronomy, Madison, WI.

Bradford, J.M. 1986. Penetrability, pp. 463-478. In Klute, A. (Ed.). Methods of Soil Analysis, Part 1 (2nd ed.). American Society of Agronomy, Madison, WI,

Day, S.D. , and N.L. Bassuk. 1994. A review of the effects of soil compaction and amelioration treatments on landscape trees. J. Arboric. 20(1):9-17.

Dexter, A.R. 1987. Mechanics of root growth. Plant Soil 97(2):401-406.
Duval, J.R., F.J. Dainello, V.A. Haby, and D.R. Earhart. 1998. Evaluating leonardite as a crop growth enhancer for turnip and mustard green. HortTechnology 8(4):564-567.

Funk, R. 2003. The effect of fertilization source and placement on tree growth, pp. 83-86. In Siewert A., A., Siewert, B. Rao, and D. Marion (Eds.). Tree and Shrub Fertilization: Proceedings from an International Conference. International Society of Arboriculture, Champaign, IL.

Gilman, E.F. 1994. Establishing trees in the landscape, pp. 69-77. In Neely, D., and G.W. Watson (Eds). The Landscape Below Ground: Proceedings of an International Workshop on Tree Root Development in Urban Soils. International Society of Arboriculture, Champaign, IL.

Gilman, E.F., and T.H. Yeager. 2003. Fertilizer rate and type impacts transplanted trees in sandy landscape soils, pp. 87-92. In Siewert A., A., Siewert, B. Rao, and D. Marion (Eds.). Tree and Shrub Fertilization: Proceedings from an International Conference. International Society of Arboriculture, Champaign, IL.

Greenly, K.M., and D.A. Rakow. 1995. The effects of wood mulch type and depth on weed and tree growth and certain soil parameters. J. Arboric. 21:255-232.

Harris, R.W, J.R. Clark, and N.P. Matheny. 2004. Arboriculture: Integrated Management of Landscape Trees, Shrubs, and Vines (4th ed.). Prentice Hall, Upper Saddle River, NJ.

Herms, D.A. 1998. Understanding tree responses to abiotic and biotic stress complexes. Arborist News 7(1):9-15.

Kelting, M.P. 1997. Effect of soil amendments and biostimulants on the post-transplant growth of landscape trees. M.S. thesis, Virginia Polytechnic Institute and State University, Blacksburg, VA.

Marion, D.F. 2003. Tree fertilization in the 21st century: Where to from here? pp 3-5. In Siewert A., A., Siewert, B. Rao, and D. Marion (Eds.). Tree and Shrub Fertilization: Proceedings from an International Conference. International Society of Arboriculture, Champaign, IL.

Miedema, R., T.H. Pape, and G.J. Van De Wall. 1974. A method to impregnate wet soil samples, producing high quality thin sections. Neth. J. of Agric. Sci. 22:37-39.

Miller, R.W. 1998. Tree fertilization: Science, myth and ethics. Arborist News 7(6):25-27.

2003. Practical application: Are we asking the right question and looking in the right places, pp. 15-20. In Siewert A., A., Siewert, B. Rao, and D. Marion (Eds.). Tree and Shrub Fertilization: Proceedings from an International Conference. International Society of Arboriculture, Champaign, IL. 
Moran, R. 1982. Formulae for determination of chlorophyllous pigments extracted with N,N-dimethylformamide. Plant Physiol. 69:1376-1381.

Murphy, C.P. 1986. Thin Section Preparation of Soils and Sediments. AB Academic Publishers, Hertfordshire, UK.

NRCS Soil Quality Institute. 1999. Soil Quality Test Kit Guide. USDA Agriculture Research Service and Natural Resources Conservation Service.

Obreza, T.A., and R.H. Biggs. 1989. Humate materials: Their effects and use as soil amendments. Citrus Industry 10.

Pagliai M., and N. Vignozzi. 2002. The soil pore system as an indicator of soil quality. Adv. GeoEcol. 35:69-80.

Pagliai, M., M. La Marca, G. Lucamante, and L. Genovese. 1984. Effects of zero and conventional tillage on the length and irregularity of elongated pores in a clay loam soil under viticulture. Soil Till. Res. 4:433-444.

Pellegrini S., N. Vignozzi, and M. Pagliai. 2000. Effects of different management systems on soil structure and compaction of two soils under viticulture. Agric. Med. 130:216-222.

Rakow, D.A. 1992. Soil Amendments in Landscape Plantings, Home and Grounds. Cornell Cooperative Extension Fact Sheet 700.30. Cornell University, Ithaca, NY.

Schafer, R.L., C.E. Johnson, A.J. Koolen, S.C. Gupta, and Horn R. 1992. Future research needs in soil compaction. Trans. ASAE 35:1761-1770.

Smalley, T.J., and C.B. Wood. 1995. Effect of backfill amendments on growth of red maple. J. Arboric. 21(5):247-249.

Struve, D.K. 2002. A review of shade tree fertilization research in the United States. J. Arboric. 28(6):252-263.

Vetterlein, D., and R.F. Hüttl. 1999. Can applied organic matter fulfill similar function as soil organic matter? Risk-benefit analysis for organic matter application as a potential strategy for rehabilitation of disturbed ecosystems. Plant Soil 213:1-10.

Watson, G.W. 1993. Influence of backfill soil amendments on establishment of container-grown shrubs. Hort Technology 3(2):188-189.

Watson, G.W., and E.B. Himelick, 1997. Principles and Practice of Planting Trees and Shrubs. International Society of Arboriculture, Champaign, IL.
Wyman, D. 1936. Growth Experiments with Pin Oak Which Are Growing Under Lawn Conditions. Cornell University Agricultural Experiment Station Bulletin 646. Cornell University, Ithaca, NY.

Aknowledgments. Support for this project came in part from the Regione Lombardia (Italy) as part of a research project on tree planting techniques in the urban environment. The authors are grateful to Dr. Gary W. Watson and Dr. Roger Harris for their review of the draft of the original and for their suggestions.

${ }^{1 *}$ Associate Professor of Urban Arboriculture and Nursery Techniques

Dipartimento di Produzione Vegetale

University of Milan

Via Celoria, 2 - 20133

Milano, Italy

Francesco.Ferrini@unimi.it

${ }^{2}$ Associate Professor of Nursery Techniques

Dipartimento di Ortoflorofrutticoltura

University of Florence

Via Donizetti, 6 - 50144

Florence, Italy

${ }^{3}$ Unità Operativa Verde Pubblico, Zone 5

City of Florence

Via Lambruschini 33

Florence, Italy

${ }^{4}$ Assistant Professor and Research Assistant, respectively Istituto Sperimentale per lo Studio e la Difesa del Suolo Sezione di Fisica del Suolo

Piazza M. D’Azeglio, 30 - 50121

Florence, Italy

*Corresponding author.

The authors contributed in equal measure to this paper. 
Résumé. Linfluence de la fertilisation et des amendements de sol sur la croissance des végétaux et les échanges foliaires gazeux ont été suivis sur des chênes anglais (Quercus robur L.) durant une période de trois ans après la plantation. Les résultats indiquent que la croissance des pousses, la surface foliaire, le contenu en chlorophylle et les échanges foliaires gazeux se sont avérés plus élevés chez les plants fertilisés, notamment durant la seconde et la troisième année après la plantation. Cependant, les plants avec compost et la leonardite étaient rarement supérieurs par rapport aux plants-témoin. Les caractéristiques physiques de sol étaient positivement influencées par les amendements de sol qui fournissaient une meilleure structure et une plus faible résistance à la pénétration comparativement aux plants-témoin et à ceux fertilisés.

Zusammenfassung. Bei Englischen Eichen wurde der Einfluss von Düngung und Bodenverbesserung auf das Pflanzenwachstum und den Blattgasaustausch über eine Periode von 3 Jahren nach der Pflanzung überwacht. Die Resultate zeigen, dass das Triebwachstum, Blattfläche, Chlorophyllgehalt und Blattgasaustausch bei gedüngten Pflanzen besonders im zweiten und dritten Jahr nach der Pflanzung größer war. Trotzdem waren Kompost und Leonardit selten besser als die Kontrollen. Die bodenphysikalischen Eigenschaften wurden durch die Bodenverbesserung positiv beeinflusst, welche zu einer besseren Struktur führte und den Penetrationswiderstand gegenüber Kontrolle und Düngung herabsetzte.

Resumen. Se monitoreó la influencia de la fertilización y los mejoradores de suelo sobre el crecimiento de las plantas e intercambio de gases en árboles de encino (Quercus robur L.) en un período de tres años después de la plantación. Los resultados indican que el crecimiento de los brotes, el área foliar, el contenido de clorofila y el intercambio gaseoso, fueron más altos en las plantas fertilizadas, especialmente durante el segundo y tercer año después de la plantación. Sin embargo, la composta y la leonardita fueron escasamente mejores que el control. Las características físicas del suelo estuvieron influenciadas positivamente por los mejoradores de suelo, los cuales promovieron mejor estructura y disminuyeron la resistencia a la penetración, comparados con los controles y la fertilización. 